Liubov Bozhko, Doctor of Cultural Studies, Associate Professor, Kharkiv State Academy of Culture, 79/42, Pushkinska str., Kharkiv, 61023, Ukraine, ORCID: 0000-0003-1989-350X ResearcherID: AAI-6889-2020

Olena Bilyk, Doctor of Pedagogical Sciences, Associate Professor, Kharkiv State Academy of Culture, 29/54, Svitla str., Kharkiv, Ukraine ORCID: 0000-0001-5468-2076 ResearcherID: AAI-5949-2020

Alina Borysova, Candidate of Psychologic Sciences, Associate Professor, Kharkiv State University of Food Technology and Trade, 43, O.Yarosha str., Kharkiv, Ukraine ORCID: 0000-0003-3323-4463 ResearcherID: AAI-4677-2020

\title{
EDUCATIONAL TOURISM: SOCIO-CULTURAL ADAPTATION STRATEGIES OF INTERNATIONAL STUDENTS IN UKRAINE
}

The article deals with the main stages of educational tourism research, identifies and substantiates the key problems of sociocultural adaptation of international students in Ukraine. The strategies of sociocultural adaptation of international students in the educational and cultural environment of the institution of higher education are considered on the example of Kharkiv State Academy of Culture (KhSAC) and Kharkiv State University of Food Technology and Trade (KSUFTT). They are aimed at the development of positive motivation concerning active inclusion of international students in the process of forming their own interethnic tolerance and learning. The series of measures within the framework of the strategies forsociocultural adaptation contributed to deepening of social knowledge of international students regarding intercultural interaction in non-traditional educational and cultural environment of Ukrainian higher educational institutions, assimilation of social values of non-traditional educational and cultural environment, and sociocultural space of Ukraine.

Keywords: educational tourism, foreign student, higher education, regulatory base, strategy. 
Relevance of the research topic. Since the second half of the twentieth century, educational tourism began to develop in Europe, primarily, specific forms of student educational tourism. The pace of this trend development has been steadily increasing, and in 2004, the World Tourism Organization (WTO) drew attention to the necessity of developing educational tourism industry using the benefits of a wide range of education and use of available methods [30].

Modern young generation want to acquire new knowledge for successful personal realization in the context of dominating information technologies and global dynamic changes. Therefore, integration of national education into the world education system and training of new-type professionals who possess the fundamentals of intercultural communication and language tools is becoming a top priority in the training of modern specialists. Intense interaction of various cultures, active exchange of material and spiritual values, globalization processes in the modern society actualize the problem of the dialogue of cultures, which is a reflection of actual forms of sociocultural interaction. Foreign culture is an important component of the basic personality culturebecause it influences the assimilation of a certain system of knowledge, norms, values, and enables proper functioning of an individual in a society.

Universities abroad are particularly popular among young people because besides education, living abroad is a huge experience that may be useful in general.

Due to the rapid development of educational tourism, a number of problems requiringsolution arise. Primarily, it is the necessity to study the process of education, training and development of an individual in the context of humanitarian and social functions of international educational tourism, cultural shock phenomena, adaptation mechanisms etc. Scientists are recording a decline in the level of human adaptation to changes in the natural and social environment [22, 137-44], so it is difficult to overestimate adaptive role of educational tourism, which offers effective mechanisms and means of physical, psychological and intellectual adaptation of an individual. The subjects of educational tourism (educational tourists) are foreign students who come to the country to obtain high quality education.

Higher education of Ukraine faces the task of modernizing the process of teaching international students, creating modern background for the formation of professional competence of future specialists for foreign countries, social development of aninternational student personality, improving the quality of vocational education, which will contribute to the competitiveness of Ukrainian international higher education services. Successful sociocultural adaptation of foreign students in a new educational and cultural environment of a higher education institution in the country of study becomes one of the conditions for the realization of this task.

Formulation of the problem. According to the official statistics presented by the Ministry of Education and Science of Ukraine (2018), about 75.605 international students from 154 countries of the world studied at the universities of Ukraine [24]. 
Ukraine is a European country, and therefore, European standards and values are fully reflected in educational programs of Ukrainian educational institutions. In Ukraine, there are higher educational institutions, which were created more than 200 years ago.They have a wealth of experience in providing educational services to international students. Most of the universities as well as foreign students are located in Kharkiv. Rather popular are the universities of Kyiv, Sumy, Lviv, and Odessa.

Effectiveness and attractivenessof vocational training for foreign students largely depend on the emotional and psychological satisfaction of the educational process, on the effectiveness of mastering the language of study as a means of communication and mastering the profession. As a result, the search for innovative methods used in professional training of foreign students, the development of new learning technologies, and identification of the main directions of sociocultural adaptation of international students are an urgent scientific problem.

The purpose of the research is to highlight the strategies of sociocultural adaptation of international students in Ukraine within the framework of educational tourism (based on the example of Kharkiv State Academy of Culture and Kharkiv State University of Food Technology and Trade).

\section{Analysis of recent researches and publications.}

International student travels and issues affecting these students have long been a topic for research in the academic community. The first research of the 1950s mainly concerned psychological issues relating to life abroad and adaptation problems that students face [26]. Numerous studiesof this period focused on the detrimental influence of the new culture on educational tourists [2;14]. Therefore, A. Bandura (1977) proposed the theory of social education, and G. Hofstede (1984) began studying cultural novelty and adjusting cultural distance that arises during the relocation from one cultural environment to another. In his opinion, the greater is the cultural difference between the country of origin and the country of residence, the greater is the difficulty in adaptation experienced by a person [4]. The inappropriateness of social behavior that is considered reasonable at home and unacceptable in the country of study causes some concern for students and can be an obstacle to proper adaptation.

J. Fan and J. Wanous pointed out that essentially there were two adaptation surroundings: adaptation-organizational and cultural [10]. Ward and Kennedy emphasize the ability to interact effectively with the host culture [28]. Much of the previous studies, in the context of intercultural studies, analyzed culture as a cause of maladaptation, not as an effect $[15 ; 23]$. Somekh and Lewin in detail described adaptation forms for displaced persons and students [19]. In subsequent studies, the paradigm of cultural perseverance began to be questioned $[1 ; 9 ; 29]$.

Subsequent research reflected changes in cognitive paradigms from the positivist medical model to an interpretivist approach that included analysis of studying culture and development of coping skills. An example of such research is the 
work of Zhou and others [31], who analyzed changes in psychological theory that included the ABC Triad (influence, behavior, and cognition) of cultural adaptation. This model of studyingculture led to training and preparation of individuals for traveling abroad. The works of Ward and Kennedy (Sociocultural Adjustment Scale) [25; 27], Farnham (Language Competence) [11], Ward and Searle (Cultural Stability) are of particular interest in researching acculturation [18]. However, there is still no single theory, which could synthesize relevant research regarding students' acculturation processes.

Now the main direction of research in this area is to identify technological features for the organization of educational tours and analyze the tendency to understand tourism as a specific form of education $[6 ; 12 ; 13]$.

The study of educational tourism has not yet received much attention in modern research in Ukraine. There are few worksconcerning international educational tourists traveling to Ukraine for further study [16]. Scientists study individual processes and stages of social and professional formation of international students, mostly their adaptation, considering it as social [7;8], intercultural [5], and sociocultural [20].

International students, unlike Ukrainian students, face the necessity to immerse themselves in both new knowledge (vocational education) and new culture (acculturation) [3]. Foreigners should acquire not only professional skills, but also master the culture of the host countrythat attracts them to the spiritual wealth of the ethnos in the country of their study.It becomes the key to the formation of creative personality, the development of such professionally important personality traits as tolerance and respect for other cultures [21, p.13]. That is why in their scientific works,researchers of the problems of international students' multicultural education $[17 ; 32]$ emphasize the importance of formingin foreign students not only professional, but also social, general cultural values and qualities, which can be interpreted as intercultural in relation to foreign students.

Presenting main material. Currently, the number of international students is one of the largest in modern history. Educational tourists are the persons who voluntarily and temporarily reside abroad in order to participate in a study exchange with the intention of returning to their country when they reach the purpose of their journey. These tourist students migrate from one cultural context to another for a relatively long time (from 6 months to 5 years).

During the last decade, Ukraine has begun accepting a large number of students from overseas universities who are attracted by the language, favorable economic and climatic conditions and prestige of Ukrainian universities. International students have to deal with a psychological phenomenon called acculturation, the process of psychological and cultural changes that results from intercultural contact.

The stay of foreign students in the Ukrainian sociocultural space presupposes situations governed by the norms of two cultures, i.e., there arise situations of cultural crossing, in which the communicative act receives interpretation from the positions of 
two cultures. The perception and assimilation of a foreign culture helps educational tourists to understand their role as subjects of the dialogue of cultures, develops skills of self-determination and self-realization in the field of intercultural interaction. Contemporary sociocultural situation, in which the personality of a foreign student is found on the border of cultures, requires him to carry on dialogues, understand, and respectthe other personfor «cultural identity». Taking into account that foreign students find themselves in a new culture as fully formed personalities (average age of foreign students is 20-25 years), bearers of their own cultural values and stereotypes, during their socialization, should be based on fundamental provisions of the dialogue of cultures concept. This concept isprimarily realized in the educational and cultural environment of a higher educational institution, since education as a sociocultural phenomenon is a factor of socialization and sociocultural adaptation of an individual and is carried out not only as a process of knowledge transfer, but as a means of cultural values transmission.

Instrumental methodological principlesused in defining strategies for sociocultural adaptation of foreign students as educational tourists, are general scientific approaches:

- cultural - to clarify the essence of intercultural communication and peculiarities of sociocultural adaptationto the information society;

- axiological - to take into account the system of value orientations of a personalityliving in the conditions of alien culture;

- acmeological - to specify the conditions of optimal professional and social development of a young person.

Sociocultural adaptation of international students in the system of Ukrainian higher education is a characteristic of their psychological and social readiness to integrate into the new society and culture of the host country, above all to educational and cultural environment of a higher education institution. At the same time, international students accept a certain way of life, occupation, culture of the society,new for them.Ifthis does not happen, international students are forced to leave the country and return to their mother country without realizing the purpose of their arrival in Ukraine - without receiving higher education.

Despite the fact that the number of suchstudents is not significant (15-20\%), it occurs in the modern educational process with simultaneousmaintenance of the most important life principles, habits, lifestyle and image of a chosen profession in a student's home country, since limited stay in Ukraine necessitatessaving the results of socialization acquired at home. The dialogue of cultures creates spiritual space for new values and worldview orientations, enhances various forms of cooperation, anticipates freedom and self-determination of an individual.

Sociocultural adaptation implies adaptation of international students to the educational process and new sociocultural reality. The main task of the representatives from higher educational institutions is to protect international students from the 
destructive influence of sociocultural space of Ukraine and educational-cultural environment of the institutions of higher learning. Socio-pedagogical protection of international students provides for guaranteeing them full social development in the conditions of new educational-cultural environment and culture, performs compensatory function, since it compensates international students for the absence of family, friends, habitual sociocultural environment. That is why it is very important to carry out adaptation training, special courses, and cultural assimilators for them.

Sociocultural adaptation of international students relates to overcoming «cultural shock», adaptation to the requirements of Ukrainian higher education. The purpose of sociocultural adaptation of international students is to form the ability to navigate in a new educational-cultural environment of a higher educational institution and sociocultural space of Ukraine, to develop adaptation and motivational potential. Its tasks are:

- to ensure active adaptation of international students to the conditions of new educational and cultural environment of ahigher educational institutionthat is unconventional for them;

- to become resilient to the influence of the new environment;

- to meet emotional, cognitive and social needs of international students;

- to create preconditions for productive social interaction of foreign students with the representatives of educational and cultural environment of a higher educational institution;

- to form motivational background of educational and professional activity of foreign students in educational and cultural environment of a higher educational institution;

- to organize social and pedagogical protection forinternational students.

In the process of sociocultural adaptation, students acquire basic social valuesof the new society in comparison with those acquired at home, and form positive motives for their educational and sociocultural activities. Staying in an unusual society, alien culture, and the necessityto participateactively in the educational process are stressful factors for foreign students that impede successful learning and life organization. The problems encountered by foreign students in a new educational and cultural environment are especially acute at this particular timethat causes personal conflicts, psychological disorders, leads to depression and frustration. Ignorance of the language of instruction makes communication in a new educational and cultural environment more difficult that requires considerable attention from the faculty and staff of the structural units responsible for foreign students training.

For the implementation of constant intercultural exchange of the representatives of the Ukrainian sociocultural space, in particular Ukrainian students, the Center for Intercultural Communication and Social Integration of Foreign Students was founded at Kharkiv State Academy of Culture, and International Academic Association was opened in Kharkiv State University of Food Technology and Trade. Their activitiesare 
directed towards the implementation of strategies for sociocultural adaptation of international students:

- improvement of educational and cultural environment as a medium of foreign students' self-realization;

- providing social and pedagogical protection, social and pedagogical assistance and support to foreign students in order to overcome «cultural shock» and their successful sociocultural adaptation,

- arrangement of socio-educational conditions for creative social and cultural cooperation;

- coordination of socio-educational influences of educational and cultural environments.

Sociocultural adaptation of international students to the conditions of new educational and cultural environment of KhSACand KSUFTT as well asto the sociocultural space of the country optimizes interaction of foreign students with this environment.Accordingly, the following forms of work are used for the implementation of the strategies for sociocultural adaptation of international students at these institutions of higher learning:

- virtual tours, workshops, exhibitions; virtual acquaintance with the future profession;

- conductinginteractive lessons «Let's get acquainted»;

- writing an essay «Why I came to Ukraine»;

- preparation of photo and video reports «How I see Ukraine», «The city where I study», «My University»;

- preparation of video reports and presentations about their country, hometown, cultural traditions of the native country of foreign students; excursions, evenings, holidays, tea parties;

- acquaintance of foreign students with the administration, faculty, staff, corporate culture and infrastructure of a higher educational establishment.

Developmentof foreign students' valuable attitude to the Ukrainian culture and society was facilitated by such events as literary and artistic evenings: «Meet Ukraine», «Song traditions of Slobozhanshchina»; «Spiritual Landmarks of Ukrainian Literature»; theatrical educational events «Ukrainian Evenings», «Ukrainian Christmas», «Pancake Week», «Easter in Ukraine»; conducting master classes «Mysteries of Ukrainian cuisine», «Rag doll», «Wonders of Ukrainian embroidery», «Opishnya ceramics», «Ukrainian Easter egg», presentations «National cuisines», «Dialogue in the kitchen», virtual tours and exhibitions. The purpose of numerous activities is to provide emotional comfort in the educational and cultural environment of the educational space, and to make international students aware of the need for selforganization of their life path. Virtual tours and presentations «My future profession» helped to form valuable attitude to their place in the educational and cultural environment of the higher educational institution and their future profession. 
Also with the involvement of psychologists at this stage fairytale therapy «Write your fairy tale», art therapy (isotherapy «Shape your emotions», «Draw your dream», music therapy «World of Ukrainian music», dance therapy «I know how to dance»), psychological counseling concerning personal problems of international students. These measures helped to provide them with emotional comfort in the educational and cultural environment, successfully overcome «cultural shock».

Excursions, visits to museums, theaters, exhibitions, concerts, cultural events, and fairs were organized to implement the strategy of sociocultural adaptation of foreign students, related to the coordination of socio-educational influences of the educational and cultural environment of KhSAC, KSUFTT and sociocultural space of Ukraine, cityand region, as well as excursions to interesting places in Ukraine. In particular, they visited Kharkiv theaters: first of all, Kharkiv Academic Opera and Ballet Theater and Taras Shevchenko Ukrainian Drama Theater, Puppet Theater, Kharkiv Regional Philharmonic.The most popular among the students are the excursions «Sightseeing tour around Kharkiv», «Theatrical Kharkiv», «Gardens and parks of Kharkiv», «Temples of Kharkiv», «Kharkiv architectural», «History of Kharkivstreets», «KrasnokutskyDendropark» and «Parkhomov Museum of History and Art», «Skovorodinovka», «Marshal Konev’s Height», «Ancient Estates ofKharkiv Region», «Historical and Archaeological Museum «VerkhniySaltiv», «V.V.DokuchaevDendropark of Kharkiv National Agrarian University». These activities helped international students to better navigate the sociocultural space of the place of their study, contributed to the expansion of knowledge about the traditions and customs of Ukrainian culture, made it possible to gain social and personal experience.

The tours to Svyatogirsk, Izium, Chuguev, Poltava, Lviv, Odessa, Chernihiv, and Kiev took place, as well asthematicexcursions «Opishnansky ceramics», «Petrykivskypainting», «Gogolevo and Dykan'ka», «Sofiyivka - love park», «Museum of Folk Architecture Pirogovo», «Buksky Canyon», «Akhtyrka Trostyanets», «Legends of ZaporizhzhyaSich», «Khortytsia Island», «Living Kharkiv region», Hunting farm»Rakytne», «Lyubotyn - the territory of the lakes», «Zmyyv the city of legends», «Slobozhane wedding», «Trails of the ancestors of the Dvorychanshchyna». The students attended ethnographic festivals «PechenehiField», «Wedding in Malynivka», «Maslyana in Skovorodynivka», festival of song and ritual folklore «Kupala Today, Tomorrow Ivan», such events as «Great Slobozhansky Fair», «City Day». These measures were aimed at expanding the sociocultural outlook of international students, forming their valuable attitude to the Ukrainian culture and Ukrainian people, ensuring emotional comfort not only in the educational and cultural environment of the institutions of higher learning, but also in the sociocultural space of Ukraine. 
Excursions to Kharkiv museums were also constantly arranged for students to the History Museum, Art Museumand Art Gallery,S. Vasylkivskyi Museum, K.I. Shulzhenko Kharkiv Museum of Famous People, Museum of Nature, «Lilac» Art Gallery, «AVEC» Gallery of Visual Arts, «Maestro» Exhibition Gallery, «LandauCenter», «Ermilov-Center», Museum of SlobozhanshchynaFolk Art, «Ukrainian Sloboda» Ethnographic Museum, Kharkiv Literary Museum, etc. These activities were aimed at the development of knowledge about Ukrainian culture, forming students' positive attitude towards Ukraine, ensuring their emotional comfort in the sociocultural space of Ukraine.

International students, participating in cultural and artistic events held in the city, got the opportunity to be involved in both traditional and contemporary Ukrainian culture. Their knowledge was enriched with new and interesting information about traditions, customs of the Ukrainian culture, norms of behavior in the Ukrainian society, formed valuable attitude to the Ukrainian culture, developed social activity connected with mastering the traditions and norms of the Ukrainian culture.

Conclusion. There fore, the educational tourism sector can be a major educational paradigm, increasing the value of the population raising the level of education and creating new economic opportunities.

In the context of modern international education development, educational tourism is a topical direction for both the tourism industry and internationalization of higher education. Negative phenomena concerning educational tourists (international students), which occur both in the sociocultural space of Ukraine as a country of study, and in the educational and cultural environment of a higher educational institution, make it necessary to enhance social and educational influences on this category of student youth, solving the problems (linguistic, academic, informational, organizational, personal, sociocultural) that they have to overcome in a new educational environment and sociocultural space of Ukraine, and improve the strategies of sociocultural adaptation of international students.

The strategies of sociocultural adaptation of international students into the educational and cultural environment of the institution of higher education, considered on the example of Kharkiv State Academy of Culture, and Kharkiv State University of Food Technology and Trade are aimed at the development of positive motivation regardingtheir active inclusion in the process of forming their own interethnic tolerance and mastering the core values of a new society and a new culture. A number of measures within the framework of the strategies of sociocultural adaptation facilitate the deepening of social knowledge of foreign students on intercultural exchange in non-traditional educational and cultural environment of the Ukrainian institutions of higher learning, assimilation of social values of the non-traditional educational and cultural environment and sociocultural space of Ukraine as a country of their study. 


\section{REFERENCES}

1. Adams, M., (2005). American Backlash: the Untold Story of Political Change in the United States. The Penguin Group, New York.

2. Bandura, A. (1977) Social Learning Theory, Englewood Cliffs, NJ: Prentice Hall.

3. Bilyk O.M. Socio-pedagogical support of international students' socialization: experience of practical implementation in educational and cultural environment of an institution of higher learning [Electronic resource] // ScienceRise :Pedagogikal Education. 2017. No 4 (12). P. 30-37. URL: http://journals.uran.ua/ sr_edu/article/view/-100404/95949

4. Black, J.S. Mendenhall, M. (1991) The U-Curve Adjustment Hypothesis Revisited: A Review and Theoretical Framework. Journal of International Business Studies, Vol. 22(2), pp. 225-247.

5. Borysova A.O. Transformation of the world picture of international students in the process of intercultural adaptation in the country of study: abstr. diss....Cand. Psych. Sciences: 19.00.07 «Pedagogical and age psychology» / G.S. Skovoroda Kharkiv Nat. Ped. Univ. Kharkiv, 2016. 22 p.

6. Brent W. Ritchie. Managing educational tourism / Brent W. Ritchie, Neil Carr, Christopher P. Cooper. - London: CromwellRpess, 2003. - 260 p.

7. Burakova K.V. Analysis of significant components of foreign students' social adaptation to study at higher educational institutions of Ukraine at the initial stage // Bulletin of Taras Shevchenko Lugansk National University: Pedagogical Sciences: Coll. of scientific works. Lugansk, 2010. No 7, part 1. P. 48-55.

8. Dean Xin. Psychological support for Chinese students' social adaptation in Ukraine: abstract diss. ... Cand. Psych. Sciences: 19.00.07 «Pedagogical and age psychology» / K.D. Ushinsky South-Ukr. National Ped. Univ. Odessa, 2009. 20 p.

9. Erez, M., Gati, E., (2004) A dynamic, multi-level model of culture; from the micro level of the individual to the macro level of a global culture. Applied Psychology: An International Review, Vol. 53 (4). pp. 583-598.

10. Fan, J., Wanous, J. (2008). Organizational and Cultural Entry: A New Type of Orientation Program for Multiple Boundary Crossings. Journal of Applied Psychology,Vol. 93, No. 6, pp. 1390-1400.

11. Furnham, A. (1993) Communicating in Foreign Lands: The Cause, Consequences and Cures of Culture Shock. Language, Culture and Curriculum,Vol. 6, pp. 91-109.

12. Greg Richards (2008) New Horizons II - The Young Independent Traveller, Amsterdam: WYSE, $37 \mathrm{p}$. 
13. Greg Richards (2009). ALTO's Global Directions in Language Travel, Amsterdam: WYSE, $36 \mathrm{p}$.

14. Hofstede, G., (1984). Cultural Dimensions in Management and Planning. Asia Pacific Journal of Management.

15. Kirkman, B., Lowe, K., Gibson, C. (2006) A quarter century of culture's consequences: a review of empirical research in incorporating Hofstede's cultural values framework. Journal of International Business Studies, Vol. 37,(3), pp. 285-320.

16. Klock O. P. (2015). Components of educational tourism development strategies in Ukraine // Effective Economics No 11.

17. Mayatskaya N.K. Scientific and pedagogical support of foreign students' acculturation in Russian universities: diss....Cand. Ped. Sciences: 13.00.08 «Theory and methodology of vocational education» / North-Caucasus State Univ. Stavropol, 2003. $181 \mathrm{p}$.

18. Searle, W., Ward, C. (1990). The prediction of Psychological and Sociocultural Adjustment during Cross-cultural Transitions. International Journal of Intercultural Relations,Vol. 14, pp. 449-464.

19. Somekh, B., Lewin, C. (2005). Research Methods in the Social Sciences. Sage Publications.

20. Steimiller I.O. Scientific and methodological support of foreign students' acculturation at classical university: abstract diss....Cand. Ped. Sciences: 13.00.07 «Theory of teaching» / V.N. KarazinKharkiv Nat. Univ. Kharkiv, 2015. 20 p.

21. Stenina N.S. Formation of Professional Competence of Foreign Students Studying at Higher Art Educational Institutions in Russia: Abstract diss....Cand. ped. Sciences: 13.00.08 «Theory and methodology of vocational education». M., 2007. 20 p.

22. Tkachuk L.M. Educational tourism in the world and Ukraine // Scientific Bulletin of the Institute of International Relations of NAU [Text]: Coll. of scientific works. - Issue No 2. - K. : National Aviation University, 2010. - P. 137-144. (Series: Economics, Law, Political Science, Tourism).

23. Tsui, A.S., Nifadkar, S.S., Ou, A.Y., (2007) Cross-national, cross-cultural organizational behavior research: advances, gaps, and recommendations. Journal of Management,Vol. 33 (3), pp. 426-476.

24. Ukrainian State Center for International Education https://studyinukraine.gov.ua

25. Ward, C., \& Kennedy, A. (1993a). Where's the culture in cross-cultural transition? Comparative studies of sojourner adjustment. Journal of Cross-cultural Psychology, 24, pp. 221-249.

26. Ward, C., Bocher, S., \&Furnham, A. (2001). The psychology of culture shock (2 ed.). Hove, East Sussex: Routledge. 
27. Ward, C., Kennedy, A. (1993b). Psychological and sociocultural adjustment during cross-cultural transitions: A comparison of secondary students overseas and at home. International Journal of Psychology, Vol. 28, pp. 129-147.

28. Ward, C., Kennedy, A. (1996a). Crossing Cultures: The Relationship between Psychological and Sociocultural Dimensions of Cross-cultural Adjustment. In Pandey, J., Singha, D., Bhawuk, D. Asia Contributions to Cross-cultural Psychology, pp. 289-306. New Delhi Sage.

29. Ward, C., Rana-Deuba, A. (2000). Home and Host Culture Influences on Sojourner Adjustment. International Journal of Intercultural Relations, Vol. 24, pp. 291-306.

30. World Tourism Organization (2004a), Tourism Congestion Management at Natural and Cultural Sites, UNWTO, Madrid.

31. Zhou, Y., Jindal-Snape, D., Topping, K., Todman, J. (2008). Theoretical Models ofCulture Shock and Adaptation. International Students in Higher Education. Studies in Higher Education, Vol. 33, No. 1, pp. 63-75.

32. Zozulya I.E. Multicultural education of international students at higher technical educational institutions: diss....Cand. Ped. Sciences: 13.00.07 «Theory and methodology of education»/Vinnitsa. Nat. Tech. Univ. Vinnitsa, 2012. 283 p. 